\title{
Response of broilers to graded levels of microbial phytase added to maize-soyabean-meal-based diets containing three levels of non-phytate phosphorus
}

\author{
BY E.T. KORNEGAY*, D. M. DENBOW, Z. YI AND V. RAVINDRAN $\dagger$ \\ Department of Animal and Poultry Sciences, Virginia Polytechnic Institute and State University, \\ Blacksburg, Virginia 24061-0306, USA
}

(Received 4 May 1995 - Revised 29 September 1995 - Accepted 31 October 1995)

\begin{abstract}
Male 1-d-old broilers ( $n$ 920) were given $0,200,400,600,800,1000$ and $1200 \mathrm{U}$ microbial phytase/kg diet in combination with $2.0,2.7$ or $3.4 \mathrm{~g}$ non-phytate $P(\mathrm{nP}) / \mathrm{kg}$ or $4.0,5.1$ or $5.8 \mathrm{~g}$ total $\mathrm{P}(\mathrm{tP}) / \mathrm{kg}$ in a $21 \mathrm{~d}$ trial to assess the effectiveness of phytase in a maize-soyabean-meal diet. In addition to the above twenty-one diets, a positive control $P$ diet supplied $4.5 \mathrm{~g} \mathrm{nP} / \mathrm{kg}, 6.9 \mathrm{~g} \mathrm{tP} / \mathrm{kg}$ and $10 \mathrm{~g} \mathrm{Ca} / \mathrm{kg}$. The basal diet contained $230 \mathrm{~g}$ crude protein $/ \mathrm{kg}, 8.8 \mathrm{~g} \mathrm{Ca} / \mathrm{kg}, 4.4 \mathrm{~g} \mathrm{tP} / \mathrm{kg}$ and $2.0 \mathrm{~g} \mathrm{nP} / \mathrm{kg}$. Defluorinated phosphate and limestone were used to supply $P$ and $C a$. A Ca:tP ratio of 2:1 was maintained except in the positive control diet which had a ratio of 1.45:1. Phytase additions linearly increased $(P<0.01)$ body-weight (BW) gain, feed intake, toe ash percentage, and apparent retention (\% of intake) or total amount $(\mathrm{g} /$ bird) of retained $\mathrm{Ca}$ and $\mathrm{P}$, and linearly decreased $(P<0.01) P$ excretion $(\mathrm{g} / \mathrm{kg}$ of $\mathrm{DM}$ intake) at each level of $\mathrm{nP}$ with the magnitude of the response inversely related to the level of $\mathrm{nP}$. Abovenormal mortality was only observed in the group receiving $2.0 \mathrm{~g} \mathrm{nP} / \mathrm{kg}$ diet without phytase. Adding $\mathrm{nP}$ linearly increased $(P<0.01) \mathrm{BW}$ gain, feed intake, toe ash percentage, $\mathrm{Ca}$ retention, total amount $(\mathrm{g} / \mathrm{bird})$ of $P$ retained, and $P$ excretion, and linearly decreased $(P<0.01)$ apparent retention $(\%)$ of $P$. Derived linear and non-linear equations for $\mathrm{BW}$ gain and toe ash percentage at the two lower $\mathrm{nP}$ levels, 2.0 and $2.7 \mathrm{~g} / \mathrm{kg}$, were used to calculate $P$ equivalency values of microbial phytase. The results show that $939 \mathrm{U}$ microbial phytase is equivalent to $1 \mathrm{~g} P$ from defluorinated phosphate in broilers fed on maize-soyabean-meal diets. The amount of $P$ released per $100 \mathrm{U}$ phytase decreased as the total amount of phytase increased.
\end{abstract}

Phytase: Broilers: Phosphorus

It has been well documented that microbial phytase is effective in releasing a significant portion of the phytate $P$ present in maize and soyabean meal and making it available to broilers (Nelson et al. 1968; Simons et al. 1990; Schoner et al. 1991). P excretion by broilers can be reduced when supplemental phytase is included in the diets (Schoner et al. 1990, 1991 ; Simons et al. 1990). The amount of $P$ excreted is related to the non-phytate and total $\mathbf{P}$ fed and to the level of supplemental phytase. Body-weight (BW) gain and toe ash percentage are sensitive indicators for assessing the efficacy of phytase for broilers and turkey poults fed on soyabean-meal-based semi-purified diets (Denbow et al. 1995; Ravindran et al. 1995a) and for evaluating $\mathrm{P}$ availability in broilers and turkey poults fed on maize-soyabean-meal diets (Potter, 1988; Potter et al. 1995). Apparent retention (\%) or total amount of retention ( $\mathrm{g} / \mathrm{bird}$ ) of $\mathrm{P}$ and $\mathrm{Ca}$ by broilers may also be sensitive indicators for evaluating $P$ availability (Schoner et al. 1993). Only limited information is available about the equivalency value of phytase for inorganic $\mathbf{P}$ in broilers fed on maize-soyabean-

* For reprints.

† Current address: Department of Animal Science, The University of Sydney, Camden NSW 2570, Australia. 
meal diets. Schoner et al. (1991) reported that $700 \mathrm{U}$ microbial phytase was equivalent to $1 \mathrm{~g} \mathrm{P}$ in the form of monocalcium phosphate (MCP) when based on P retention of broilers fed on a maize-soyabean-meal diet for $14 \mathrm{~d}$; a value of $762 \mathrm{U}$ phytase was obtained when the calculation was based on crude ash in the body. Schoner et al. (1993) using a similar diet reported that $570 \mathrm{U}$ phytase was equivalent to $1 \mathrm{~g} \mathrm{P}$ as MCP based on BW gain at $14 \mathrm{~d}$ and $1050 \mathrm{U}$ phytase was equal to $1 \mathrm{~g} P$ when based on $P$ retention. At $40 \mathrm{~d}, 850 \mathrm{U}$ phytase was equal to $1 \mathrm{~g} \mathrm{P}$ for both measurements. In each of the above studies (Schoner et al. 1991, 1993), only one level of $P$ was used in each of the trials.

The purpose of the present study was: (1) to study the response of broilers to graded levels of microbial phytase added to maize-soyabean-meal-based diets containing three levels of non-phytate P (nP), (2) to evaluate several measurements for their usefulness in predicting the responses to $P$ and phytase additions, and (3) to determine $P$ equivalency values of phytase.

\section{MATERIALS AND METHODS}

Peterson $\times$ Arbor Acres male broiler chicks ( $n$ 920) were used in a $3 \times 7$ factorial arrangement of treatments with four replicates (ten birds/pen) to evaluate the response of broilers to seven levels of phytase (Natuphos ${ }^{\star}$; BASF Corp., 3000 Continental Drive North, Mount Olive, NJ 07828-1234, USA) in combination with three levels of nP. Dietary $\mathrm{P}$ levels were formulated at $2 \cdot 0,2.7$ and $3.4 \mathrm{~g} \mathrm{nP} / \mathrm{kg}$ (or $4.4,5.1$ and $5.8 \mathrm{~g}$ total $\mathrm{P}(\mathrm{tP}) / \mathrm{kg}$ ) respectively, and each level of $P$ was supplemented with $0,200,400,600,800,1000$ and $1200 \mathrm{U}$ phytase $/ \mathrm{kg}$ diet. One unit of phytase activity is defined as the quantity of enzyme that liberates $1 \mu \mathrm{mol}$ inorganic $\mathrm{P} / \mathrm{min}$ from $5.1 \mathrm{~mm}$-sodium phytate at $\mathrm{pH} 5.5$ and $37^{\circ}$ (Simons et al. 1990; Engelen et al. 1994). These dietary $P$ levels were formulated below the current National Research Council (NRC) (1994) recommendations to ensure maximum responses with phytase additions. In addition to the twenty-one diets described, a positive control diet was formulated to supply the recommended level of $4.5 \mathrm{~g} \mathrm{nP} / \mathrm{kg}$ or $6.9 \mathrm{~g} \mathrm{tP} / \mathrm{kg}$.

Composition of the diets is shown in Table 1 . Since the $\mathrm{nP}$ level of $1.5 \mathrm{~g} / \mathrm{kg}$ supplied by the maize and soyabean meal was thought to be inadequate to sustain chick life, inorganic $P$ was added $(0.5 \mathrm{~g} / \mathrm{kg})$ to increase the $\mathrm{nP}$ level to $2.0 \mathrm{~g} / \mathrm{kg}$; this level of $P$ without phytase, however, was expected to result in some mortality (Potter et al. 1995). The desired levels of $\mathrm{nP}$ and $\mathrm{Ca}$ in the basal diets were achieved by varying the levels of defluorinated phosphate and limestone at the expense of maize. The $\mathrm{Ca}: \mathrm{tP}$ ratio was maintained at $2: 1$ in all diets except the positive control diet, which had a ratio of 1.45:1. Since the phytate was supplied only from the maize and soyabean meal, the dietary content of phytate $P$ $(2 \cdot 4 \mathrm{~g} / \mathrm{kg})$ was similar in all diets.

The birds were housed in electrically heated, raised wire-floored starting batteries in an environmentally controlled room. The treatments were then randomly assigned to four pens of ten chicks each except the positive control diet which had eight pens of ten chicks each. The diets were fed in a mash form from 1 to $21 \mathrm{~d}$ of age. Birds had ad libitum access to feed and water at all times. The care and treatment of broilers followed published guidelines (Consortium, 1988). BW and feed intake were recorded on a pen basis at weekly intervals. Records of mortality were also maintained.

During the third week (days 18-20) a total collection of excreta from each pen was carried out. Feed intake and production of excreta were measured quantitatively per pen over the three consecutive days. Excreta from each pen were stored in plastic bags at $-20^{\circ}$. After thawing, excreta were dried in an oven at $70^{\circ}$ and weighed. Excreta, along with diet samples, were ground to pass a $1 \mathrm{~mm}$ sieve. Dry matter was determined according to Association of Official Analytical Chemists (1990) procedures. Following a $\mathrm{HNO}_{3}-\mathrm{HClO}_{4}$ 
wet digestion, $\mathbf{P}$ concentrations were determined photometrically (Association of Official Analytical Chemists, 1990) and $\mathrm{Ca}$ contents were determined with an atomic absorption spectrophotometer. Apparent retention values (\% of intake or $\mathrm{g} / \mathrm{bird}$ ) for $\mathrm{P}$ and $\mathrm{Ca}$ during the $3 \mathrm{~d}$ were calculated for each dietary treatment.

On day 21 , all surviving chicks were killed by cervical dislocation. Toe samples were obtained by severing the middle toe through the joint between the second and third tarsal bones from the distal end. The left middle toes of all chicks within a pen were pooled, and the right middle toes from the same chicks were pooled, yielding two samples of toes per pen. The composite samples were dried to a constant weight at $100^{\circ}$ and then ashed in a muffle furnace at $600^{\circ}$ for $4 \mathrm{~h}$ (Potter, 1988). Toe ash was expressed as a percentage of dry weight.

Data were analysed by the general linear models (GLM) procedure of Statistical Analysis Systems (1990) with pen means as the experimental unit. Linear and quadratic effects of added phytase within each $P$ level and comparisons between dietary $P$ levels without added phytase were tested using orthogonal polynomials.

In order to evaluate further the sensitive indicators for response measurements and to predict the responses of $\mathbf{P}$ and phytase levels in broilers, second-order translog equations were derived for the $3 \times 7$ factorial arrangement of treatments with the model:

$$
\ln Y=\alpha_{0}+\alpha_{1} \ln X_{1}+\alpha_{2} \ln X_{2}+\alpha_{3}\left(\ln X_{1}\right)^{2}+\alpha_{4}\left(\ln X_{2}\right)^{2}+\alpha_{5} \ln X_{1} \ln X_{2},
$$

where $Y$ is response measurement, $X_{1}$ is $\mathrm{nP}(\%)$, and $X_{2}$ is phytase added (U/ $\left.\mathrm{kg} \mathrm{diet}\right)$. The second-order translog function was chosen because Driscoll (1994) demonstrated that this function is a flexible functional form that can provide second-order approximations to any underlying function. Non-linear and linear functions were derived for the seven phytase levels at each $P$ level $(2 \cdot 0,2 \cdot 7$ and $3.4 \mathrm{~g} \mathrm{nP} / \mathrm{kg})$ and for the four $P$ levels $(2 \cdot 0,2 \cdot 7,3.4$ and $4.5 \mathrm{~g} \mathrm{nP} / \mathrm{kg})$ without phytase added, with the non-linear model: $Y=a\left(1-b \mathrm{e}^{-k X}\right)$ and the linear model: $Y=a+b X$, where $Y$ is response measurement; and $X$ is $\mathrm{nP}(\mathrm{g} / \mathrm{kg})$ or phytase added (U/ $/ \mathrm{kg}$ diet). Non-linear and linear equations for $\mathrm{nP}$ (no added phytase) and for phytase at the three levels of $\mathrm{nP}$ for all measurements were examined for high $r^{2}$.

The $R^{2}$ values of the second-order translog equations were also examined. Because of high $R^{2}$ values and economic importance or ease of obtaining, BW gain and toe ash percentage were used to generate the $P$ equivalency equations. The response equation for $\mathrm{nP}$ and the equation for added phytase at each of the two lower levels of $\mathrm{nP}$ were set equal and solved (D. M. Denbow, unpublished results). The resulting equations were used to calculate $P$ equivalency values $(\mathrm{g} / \mathrm{kg})$ at $250,500,750$, and $1000 \mathrm{U}$ phytase $/ \mathrm{kg}$ diet to enable comparisons with other reports in the literature, which often studied the addition of 500 or $1000 \mathrm{U}$ phytase $/ \mathrm{kg}$ diet. The average of the released $P$ for each of the two $P$ levels was then used to determine the amount of $P$ released expressed as a percentage of phytate $P$. The $P$ equivalency equation was derived from these four data points for amount of $P$ released. The use of a regression line (equation) from graded levels of $P$ or phytase provides a more accurate means of estimating a response than a single number. Also, the generation of a $P$ equivalency equation from the equations for $P$ and phytase allows for the calculation of the equivalency of phytase for $P$ at any point on the line. Further, the use of mathematical equations allows for the easy incorporation of this information in computer models.

\section{RESULTS}

BW gains were increased $(P<0.01)$ by dietary $P$ and phytase additions (Table 2$)$, but a $P$ level $\times$ phytase level interaction $(P<0.01)$ was observed. Gains were improved by phytase additions at all $P$ levels; however, the magnitude of the response was greatest at lower rates 
Table 1. Components and calculated composition of basal diets $(\mathrm{g} / \mathrm{kg})$

\begin{tabular}{|c|c|c|c|c|}
\hline & \multicolumn{4}{|c|}{ Non-phytate phosphorus $(\mathrm{g} / \mathrm{kg})$} \\
\hline & $2 \cdot 0^{*}$ & $2 \cdot 7^{*}$ & $3 \cdot 4^{*}$ & $4.5 \dagger$ \\
\hline \multicolumn{5}{|l|}{ Components } \\
\hline Ground yellow maize & $578 \cdot 1$ & 573.9 & $569 \cdot 8$ & 572.9 \\
\hline Soyabean meal $(485 \mathrm{~g} \mathrm{CP} / \mathrm{kg})$ & $371 \cdot 0$ & $371 \cdot 0$ & $371 \cdot 0$ & $371 \cdot 0$ \\
\hline Stabilized fat & 20.0 & $20 \cdot 0$ & $20 \cdot 0$ & $20 \cdot 0$ \\
\hline Limestone & 17.9 & $18-2$ & $18 \cdot 4$ & $9 \cdot 2$ \\
\hline Defluorinated phosphateł & $3 \cdot 0$ & 6.9 & 10.8 & 16.9 \\
\hline Vitamin premix $\$$ & $2 \cdot 0$ & $2 \cdot 0$ & $2 \cdot 0$ & $2 \cdot 0$ \\
\hline Trace mineral premix $\|$ & $2 \cdot 0$ & $2 \cdot 0$ & $2 \cdot 0$ & $2 \cdot 0$ \\
\hline Salt & 40 & $4 \cdot 0$ & $4 \cdot 0$ & $4 \cdot 0$ \\
\hline DL-Methionine & $2 \cdot 0$ & $2 \cdot 0$ & $2 \cdot 0$ & $2 \cdot 0$ \\
\hline \multicolumn{5}{|l|}{ Calculated composition } \\
\hline $\mathrm{CP}(\mathrm{N} \times 6.25)$ & $230 \cdot 7$ & $230 \cdot 4$ & $230 \cdot 0$ & $230 \cdot 3$ \\
\hline Lysine & $13 \cdot 2$ & $13 \cdot 2$ & $13 \cdot 2$ & $13-2$ \\
\hline Methionine + cystine & $9 \cdot 3$ & $9 \cdot 3$ & $9 \cdot 3$ & $9 \cdot 3$ \\
\hline $\mathrm{Ca}$ & 8.8 & $10 \cdot 2$ & $11 \cdot 6$ & 10.0 \\
\hline Total P & $4 \cdot 4$ & $5 \cdot 1$ & $5 \cdot 8$ & 6.9 \\
\hline Non-phytate $\mathbf{P}$ & $2 \cdot 0$ & $2 \cdot 7$ & $3 \cdot 4$ & $4 \cdot 5$ \\
\hline Ca:total $\mathbf{P}$ & 2.0 & $2 \cdot 0$ & $2 \cdot 0$ & 1.45 \\
\hline
\end{tabular}

$\mathrm{CP}$, crude protein.

* 0, 200, 400,600,800, 1000 and 1200 U phytase (Natuphos ${ }^{\star}$, BASF Corp., Mount Olive, NJ, USA; $5000 \mathrm{U} / \mathrm{g}) / \mathrm{kg}$ was added to each of the basal diets.

$\dagger$ Positive control diet; no phytase was added.

\$ Fine CDP, Southern Bag Corp., Valdosta, GA 31083, USA.

$\S$ Supplied (per kg diet): retinyl acetate $908 \mu \mathrm{g}$, cholecalciferol $66 \mu \mathrm{g}$, DL- $\alpha$-topheryl acetate $26 \mathrm{mg}$, menadione sodium bisulphite complex $0.75 \mathrm{mg}$, riboflavin $7.5 \mathrm{mg}$, D-calcium pantothenate $9.7 \mathrm{mg}$, niacin $26.4 \mathrm{mg}$, cyanocobalamin $0.011 \mathrm{mg}$, choline chloride $1012 \mathrm{mg}$, D-biotin $0.31 \mathrm{mg}$, pteroylmonoglutamic acid $3.1 \mathrm{mg}$, thiamin- $\mathrm{HCl} 8 \mathrm{mg}$, pyridoxine- $\mathrm{HCl} 3 \cdot 1 \mathrm{mg}$, ethoxyquin $50 \mathrm{mg}$, and virginiamycin $2.9 \mathrm{mg}$.

\|) Supplied per kg diet: $\mathrm{Mn} 88 \mathrm{mg}, \mathrm{Zn} 95 \mathrm{mg}, \mathrm{Fe} 100 \mathrm{mg}, \mathrm{Cu} 12.5 \mathrm{mg}, \mathrm{I} 4 \mathrm{mg}$, and Se $0.6 \mathrm{mg}$.

of phytase addition for the lower $\mathrm{nP}$ levels. At $2.0 \mathrm{~g} \mathrm{nP} / \mathrm{kg}$, gains improved (linear, $P<$ 0.01 ; quadratic, $P<0.01$ ) up to $1000 \mathrm{U}$ phytase $/ \mathrm{kg}$ diet and then reached a plateau. The response appeared to reach a plateau at $800 \mathrm{U}$ phytase $/ \mathrm{kg}$ diet for broilers fed on diets containing $2.7 \mathrm{~g} \mathrm{nP} / \mathrm{kg}$ (linear, $P<0.01$ ). On the $3.4 \mathrm{~g} \mathrm{nP} / \mathrm{kg}$ diet the response appeared to reach a plateau at $600 \mathrm{U}$ phytase $/ \mathrm{kg} \operatorname{diet}(P<0.01)$.

Total feed intake followed a similar pattern to that of average BW gains (Table 2). The addition of both $\mathrm{nP}$ and phytase increased feed intake with the greatest response for phytase at the lowest $\mathrm{nP}$ level $(2 \cdot 0 \mathrm{~g} / \mathrm{kg})$. Gain $/$ feed $(\mathrm{g} / \mathrm{kg})$ was improving by increasing dietary $\mathrm{nP}$ level (linear, $P<0.05$ ). The addition of phytase improved gain/feed only at $2.0 \mathrm{~g} \mathrm{nP} / \mathrm{kg}$ (linear, $P<0.01$ ).

Dietary additions of $\mathrm{nP}(P<0.01)$ and phytase $(P<0.01)$ linearly increased toe ash percentage (Table 3 ). The response to phytase was observed at all levels of $\mathrm{nP}$, although the magnitude of the response seemed to decrease as level of $\mathrm{nP}$ increased.

Retention (\% of intake and $\mathrm{g} / \mathrm{bird}$ ) of DM, Ca, and P, and excretion (g/ $\mathrm{kg} \mathrm{DM}$ intake) of $P$ during days $18-20$ are shown in Tables 4 and 5 . Increasing dietary $n P(g / k g)$ level increased (linear, $P<0.01$ ) retention ( $\%$ of intake and $\mathrm{g} /$ bird) of $\mathrm{DM}, \mathrm{Ca}$ and $\mathrm{P}$, and excretion ( $\mathrm{g} / \mathrm{kg} \mathrm{DM}$ intake) of $P$. Increasing $\mathrm{nP}(\mathrm{g} / \mathrm{kg})$ also increased the total amount (g/bird) of $P$ retained (linear, $P<0.01$; quadratic, $P<0.05$ ), but decreased apparent retention ( $\%$ of intake) of $P$ (linear, $P<0.01$, quadratic, $P<0.05$ ). Addition of graded 
Table 2. Body-weight gain, feed intake, and gain/feed of broilers fed on maize-soyabeanmeal-based diets containing varying amounts of non-phytate phosphorus and supplemental phytase from 1 to 21 d of age*

\begin{tabular}{|c|c|c|c|c|}
\hline \multirow{2}{*}{$\begin{array}{l}\text { Phytase added } \\
\text { (U/kg diet) }\end{array}$} & \multicolumn{4}{|c|}{ Non-phytate phosphorus $(\mathrm{g} / \mathrm{kg})$} \\
\hline & $2 \cdot 0$ & $2 \cdot 7$ & $3 \cdot 4$ & 4.5 \\
\hline \multicolumn{5}{|c|}{ Body-wt gain (g/bird)† } \\
\hline 0 & $380 \ddagger$ & 511 & $562 \S$ & 613 \\
\hline 200 & 487 & 544 & 581 & \\
\hline 400 & 508 & 556 & 580 & \\
\hline 600 & 524 & 564 & 595 & \\
\hline 800 & 548 & 587 & 598 & \\
\hline 1000 & 560 & 585 & 594 & \\
\hline 1200 & 557 & 595 & 612 & \\
\hline \multicolumn{5}{|c|}{ Total feed intake $(\mathrm{g} / \mathrm{bird}) \dagger$} \\
\hline 0 & $625 \ddagger$ & $835 \S$ & $906 \S$ & 963 \\
\hline 200 & 810 & $873^{\circ}$ & $915^{\circ}$ & \\
\hline 400 & 819 & 876 & 903 & \\
\hline 600 & 876 & 924 & 943 & \\
\hline 800 & 905 & 929 & 946 & \\
\hline 1000 & 860 & 918 & 933 & \\
\hline 1200 & 872 & 935 & 965 & \\
\hline \multicolumn{5}{|c|}{ Gain/feed $(\mathrm{g} / \mathrm{kg}) \|$} \\
\hline 0 & $584 \S$ & 613 & 620 & 636 \\
\hline 200 & 604 & 624 & 644 & \\
\hline 400 & 622 & 634 & 643 & \\
\hline 600 & 599 & 610 & 631 & \\
\hline 800 & 606 & 632 & 633 & \\
\hline 1000 & 652 & 638 & 637 & \\
\hline 1200 & 642 & 637 & 636 & \\
\hline
\end{tabular}

* Mean values for four pens of ten chicks each, except for the $4.5 \mathrm{~g}$ non-phytate $\mathrm{P} / \mathrm{kg}$ which are for eight pens of ten chicks each. The root mean square errors (MSE) were 26,38 , and 30 respectively for body-weight gain, total feed intake and gain/feed. The pooled SEM for a single treatment mean is MSE $/ \sqrt{ } n$.

$\dagger$ Phosphorus linear and quadratic effect $(P<0.05)$; phosphorus $\times$ phytase interaction $(P<0.01)$.

$\ddagger$ Phytase linear and quadratic effect $(P<0.01)$.

$\S$ Phytase linear effect $(P<0.01)$.

$\|$ Phosphorus linear effect $(P<0.05)$.

levels of phytase increased retention of DM (linear, $P<0.05$ ), Ca (linear, $P<0.01$; quadratic, $P<0.07$ ), and $\mathrm{P}$ (linear, $P<0.01$ ). The amount of $\mathrm{P}$ excreted was linearly decreased $(P<0.01)$ as phytase was added. In comparison with the positive control diet $(4.5 \mathrm{~g} \mathrm{nP} / \mathrm{kg}), P$ excretion was reduced by $25-54 \%$ with addition of $200-1200 \mathrm{U}$ phytase at various $\mathrm{nP}$ levels. The magnitude of the response was greatest for the lowest $\mathrm{nP}$ levels $(41-54 \%$ at $2.0 \mathrm{~g} \mathrm{nP} / \mathrm{kg} ; 34-46 \%$ at $2.7 \mathrm{~g} \mathrm{nP} / \mathrm{kg} ; 25-34 \%$ at $3.4 \mathrm{~g} \mathrm{nP} / \mathrm{kg}$ ).

Second-order translog equations of performance, toe ash percentage, apparent retention of DM, $P$ and $\mathrm{Ca}$, and $\mathrm{P}$ excretion were generated and are shown in Table 6 . The response surfaces obtained from plotting the second-order translog equations for BW gain and toe ash percentage are shown in Fig. 1. All the measurements had high $R^{2}$ values, except gain/feed and apparent retention (\% of intake) of DM which had low $R^{2}$ values. Linear or non-linear response equations were also generated with four $\mathrm{nP}$ levels $(2 \cdot 0,2 \cdot 7,3.4$ and $4.5 \mathrm{~g} / \mathrm{kg}$ ) without added phytase and with seven phytase levels at each of three $\mathrm{nP}$ levels $(2.0,2.7$ and $3.4 \mathrm{~g} / \mathrm{kg})$ for all the measurements (Table 7). The equations for all the 
Table 3. Percentage ash content of dried toes from broilers fed on maize-soyabean-mealbased diets containing varying amounts of non-phytate phosphorus and supplemental phytase from 1 to 21 d of age*

\begin{tabular}{ccccc}
\hline & \multicolumn{3}{c}{ Non-phytate phosphorus $(\mathrm{g} / \mathrm{kg}) \dagger$} \\
\cline { 2 - 5 } $\begin{array}{c}\text { Phytase added } \\
\text { (U/kg diet) }\end{array}$ & $2.0 \ddagger$ & $2.7 \ddagger$ & $3.4 \ddagger$ & 4.5 \\
\hline 0 & 8.2 & 10.0 & 11.3 & 13.3 \\
200 & 8.7 & 10.5 & 11.9 & \\
400 & 9.3 & 11.1 & 11.9 & \\
600 & 9.8 & 11.5 & 11.8 & \\
800 & 9.9 & 10.9 & 12.3 & \\
1000 & 10.5 & 11.6 & 12.2 & \\
1200 & 11.1 & 12.6 & 12.9 \\
\hline
\end{tabular}

* Mean values for four pens of ten chicks each, except $4.5 \mathrm{~g}$ non-phytate $\mathrm{P} / \mathrm{kg}$ which are for eight pens of ten chicks each. The root mean square error (MSE) was 0.6 and the pooled SEM for a single mean is MSE/ $\sqrt{n}$.

$\dagger$ Phosphorus linear $(P<0.01)$ and quadratic $(P<0.05)$ effects.

$\ddagger$ Phytase linear effect $(P<0.01)$.

Table 4. Apparent retention of dry matter and calcium during days 18-20 of broilers fed on maize-soyabean-meal-based diets containing varying amounts of non-phytate phosphorus and supplemental phytase*

\begin{tabular}{|c|c|c|c|c|c|c|c|c|}
\hline \multirow[b]{3}{*}{$\begin{array}{l}\text { Phytase added } \\
\text { (U/kg diet) }\end{array}$} & \multicolumn{8}{|c|}{ Non-phytate $P(g / k g)$} \\
\hline & \multicolumn{2}{|c|}{$2 \cdot 0$} & \multicolumn{2}{|c|}{$2 \cdot 7$} & \multicolumn{2}{|c|}{$3 \cdot 4$} & \multicolumn{2}{|c|}{$4 \cdot 5$} \\
\hline & $\begin{array}{l}\% \text { of } \\
\text { intake }\end{array}$ & g/bird & $\begin{array}{l}\% \text { of } \\
\text { intake }\end{array}$ & g/bird & $\begin{array}{l}\% \text { of } \\
\text { intake }\end{array}$ & g/bird & $\begin{array}{l}\% \text { of } \\
\text { intake }\end{array}$ & g/bird \\
\hline \multicolumn{9}{|c|}{ Dry matter retention } \\
\hline $\begin{array}{r}0 \\
200 \\
400 \\
600 \\
800 \\
1000 \\
1200\end{array}$ & $\begin{array}{l}74 \cdot 0 \ddagger \\
75 \cdot 4 \\
76 \cdot 3 \\
76 \cdot 4 \\
76 \cdot 5 \\
77 \cdot 2 \\
76 \cdot 2\end{array}$ & $\begin{array}{l}83 \cdot 0 \ddagger \\
111 \cdot 0 \\
116 \cdot 0 \\
117 \cdot 5 \\
127 \cdot 8 \\
125 \cdot 0 \\
128 \cdot 1\end{array}$ & $\begin{array}{l}75 \cdot 8 \S \\
75 \cdot 2 \\
77 \cdot 5 \\
77 \cdot 1 \\
77 \cdot 9 \\
77 \cdot 7 \\
77 \cdot 1\end{array}$ & $\begin{array}{l}116 \cdot 5 \S \\
123 \cdot 2 \\
129 \cdot 8 \\
134 \cdot 0 \\
134 \cdot 1 \\
133 \cdot 7 \\
139 \cdot 4\end{array}$ & $\begin{array}{l}75 \cdot 5 \S \\
76 \cdot 8 \\
76 \cdot 9 \\
77 \cdot 2 \\
77 \cdot 9 \\
77 \cdot 5 \\
78 \cdot 1\end{array}$ & $\begin{array}{l}131 \cdot 8 \S \\
138 \cdot 1 \\
127 \cdot 9 \\
139 \cdot 2 \\
136 \cdot 4 \\
138 \cdot 6 \\
144 \cdot 5\end{array}$ & $77 \cdot 5$ & 142.4 \\
\hline \multicolumn{9}{|c|}{ Calcium retention" } \\
\hline $\begin{array}{r}0 \\
200 \\
400 \\
600 \\
800 \\
1000 \\
1200\end{array}$ & $\begin{array}{l}52 \cdot 39 \\
51 \cdot 0 \\
50 \cdot 5 \\
53 \cdot 5 \\
53 \cdot 0 \\
57 \cdot 1 \\
58 \cdot 7\end{array}$ & $\begin{array}{l}0.6268 \\
0.810 \\
0.756 \\
0.863 \\
0.918 \\
0.996 \\
1.027\end{array}$ & $\begin{array}{l}52 \cdot 39 \\
56 \cdot 6 \\
55 \cdot 8 \\
58 \cdot 5 \\
57 \cdot 8 \\
61 \cdot 5 \\
64 \cdot 0\end{array}$ & $\begin{array}{l}1.007 \ddagger \\
1.248 \\
1.147 \\
1.215 \\
1.268 \\
1.334 \\
1.581\end{array}$ & $\begin{array}{l}54 \cdot 11 \\
55 \cdot 7 \\
57 \cdot 4 \\
54 \cdot 2 \\
57 \cdot 5 \\
55 \cdot 0 \\
62 \cdot 6\end{array}$ & $\begin{array}{l}1 \cdot 312 \\
1.376 \\
1.381 \\
1 \cdot 289 \\
1.491 \\
1.253 \\
1.643\end{array}$ & $63 \cdot 6$ & $1 \cdot 628$ \\
\hline
\end{tabular}

* Mean values for four pens of ten chicks, except $4.5 \mathrm{~g}$ non-phytate $\mathrm{P} / \mathrm{kg}$ which are for eight pens of ten chicks each. The root mean square errors (MSE) were 1.6 and 8.7, 3.0 and 0.098 respectively for DM and apparent Ca retention (\% of intake and $\mathrm{g} /$ bird). The pooled SEM for a single treatment is MSE $/ \sqrt{ } n$.

$\dagger$ Phosphorus linear effect $(P<0.01)$.

$\ddagger$ Phytase linear $(P<0.001)$ and quadratic $(P<0.07)$ effects.

$\S$ Phytase linear effect $(P<0 \cdot 05)$.

$\|$ Phosphorus linear $(P<0.01)$ and quadratic $(P<0.01)$ effects.

II Phytase linear $(P<0.01)$ and quadratic $(P<0.05)$ effects. 
Table 5. Apparent phosphorus retention and phosphorus excretion during days $18-20$ of broilers fed on maize-soyabean-meal-based diets containing varying amounts of non-phytate phosphorus and supplemental phytase*

\begin{tabular}{|c|c|c|c|c|c|c|c|c|}
\hline \multirow[b]{3}{*}{$\begin{array}{l}\text { Phytase added } \\
\text { (U/kg diet) }\end{array}$} & \multicolumn{8}{|c|}{ Non-phytate $P(g / k g)$} \\
\hline & \multicolumn{2}{|c|}{$2 \cdot 0$} & \multicolumn{2}{|c|}{$2 \cdot 7$} & \multicolumn{2}{|c|}{$3 \cdot 4$} & \multicolumn{2}{|c|}{$4 \cdot 5$} \\
\hline & $\begin{array}{l}\% \text { of } \\
\text { intake }\end{array}$ & $\mathrm{g} / \mathrm{bird}$ & $\begin{array}{l}\% \text { of } \\
\text { intake }\end{array}$ & $\mathrm{g} /$ bird & $\begin{array}{l}\% \text { of } \\
\text { intake }\end{array}$ & $\mathrm{g} / \mathrm{bird}$ & $\begin{array}{l}\% \text { of } \\
\text { intake }\end{array}$ & g/bird \\
\hline \multicolumn{9}{|c|}{ Phosphorus retention $\dagger$} \\
\hline $\begin{array}{r}0 \\
200 \\
400 \\
600 \\
800 \\
1000 \\
1200\end{array}$ & $\begin{array}{l}58 \cdot 7 \ddagger \\
60 \cdot 6 \\
59 \cdot 7 \\
61 \cdot 8 \\
62 \cdot 3 \\
66 \cdot 0 \\
67 \cdot 2\end{array}$ & $\begin{array}{l}0.348 \ddagger \\
0.506 \\
0.482 \\
0.497 \\
0.524 \\
0.559 \\
0.599\end{array}$ & $\begin{array}{l}54 \cdot 7 \ddagger \\
60 \cdot 6 \\
60 \cdot 8 \\
63 \cdot 4 \\
64 \cdot 0 \\
64 \cdot 8 \\
70 \cdot 6\end{array}$ & $\begin{array}{l}0.494 \ddagger \\
0.619 \\
0.606 \\
0.653 \\
0.677 \\
0.567 \\
0.872\end{array}$ & $\begin{array}{l}52 \cdot 1 \ddagger \\
56 \cdot 9 \\
58 \cdot 8 \\
58 \cdot 4 \\
63 \cdot 4 \\
63 \cdot 2 \\
63 \cdot 4\end{array}$ & $\begin{array}{l}0.566 \ddagger \\
0.660 \\
0.639 \\
0.672 \\
0.774 \\
0.787 \\
0.794\end{array}$ & $54 \cdot 9$ & 0.888 \\
\hline \multicolumn{9}{|c|}{ Phosphorus excretion $\S(\mathrm{g} / \mathrm{kg}$ DM intake) } \\
\hline $\begin{array}{r}0 \\
200 \\
400 \\
600 \\
800 \\
1000 \\
1200\end{array}$ & . & & & & & & & \\
\hline
\end{tabular}

* Mean values for four pens of ten chicks each, except $4.5 \mathrm{~g}$ non-phytate $\mathrm{P} / \mathrm{kg}$ which are for eight pens of ten chicks each. The root mean square errors (MSE) were 3.4, 0.06 and 0.36 respectively for apparent $P$ retention ( $\%$ of intake and $\mathrm{g} / \mathrm{kg}$ per bird) and $\mathrm{P}$ excretion. The SEM for a single treatment is MSE $/ \sqrt{ } n$.

$\dagger$ Phosphorus linear $(P<0.01)$ and quadratic $(P<0.05)$ effects.

$\ddagger$ Phytase linear effect $(P<0.01)$.

$\S$ Phosphorus linear effect $(P<0.01)$.

measurements with high $r^{2}$ values (except apparent $\mathrm{P}$ retention) at the two lower $\mathrm{nP}$ levels were used to calculate $P$ equivalency values of phytase (Table 8 ). Data for the highest level of $\mathrm{nP}(3.4 \mathrm{~g} / \mathrm{kg})$ were not used in the estimation of $\mathrm{P}$ equivalency values because $r^{2}$ values were generally lower and the response to phytase was not as large compared with 2.0 and $2.7 \mathrm{~g} / \mathrm{kg}$ levels; this would be expected since $3.4 \mathrm{~g} / \mathrm{kg}$ is much closer to the suggested NRC (1994) level of $4.5 \mathrm{~g} / \mathrm{kg}$ than 2.0 and $2.7 \mathrm{~g} / \mathrm{kg}$. The equation for $\mathrm{nP}$ and the equation for added phytase at each of the two lower levels of $\mathrm{nP}$ were set equal. For example, the equation for toe ash percentage at $2.0 \mathrm{~g} \mathrm{nP} / \mathrm{kg}$ :

$$
\begin{aligned}
21.3\left(1-0.908 \mathrm{e}^{-0.197 X_{1}}\right) & =8.28+0.0023 X_{2}, \\
X_{1} & =-5.076 \ln \left(0.6732-0.000119 X_{2}\right),
\end{aligned}
$$

where $X_{1}$ is $\mathrm{nP}(\mathrm{g} / \mathrm{kg})$ and $X_{2}$ is phytase added $(\mathrm{U} / \mathrm{kg}$ diet). The resulting equations were used to calculate the equivalent $\mathrm{P} \mathrm{nP}(\mathrm{g} / \mathrm{kg})$ at $250,500,750$, and $1000 \mathrm{U}$ phytase $/ \mathrm{kg}$ diet. For example, if phytase $\left(X_{2}\right)=500 \mathrm{U} / \mathrm{kg}$ diet, then the equivalent $\mathrm{nP}\left(X_{1}\right)=-5.076 \ln$ $(0.6732-0.000119 \times 500)$ and $X_{1}=2.50 \mathrm{~g} / \mathrm{kg}$ (Table 8). Therefore, released $\mathrm{P}=$ equivalent $\mathrm{nP}-\mathrm{nP}$ in the diet (for example, $2.50-2.0=0.50 \mathrm{~g} / \mathrm{kg}$ ). BW gain and toe ash percentage were weighted equally and averaged across the two lower $\mathrm{nP}$ levels for development of a $P$ equivalency equation: $Y=1.849-1.799 \mathrm{e}^{-0.0008 x}$ (Table 8$)$, where $Y$ is released $\mathrm{P}(\mathrm{g} / \mathrm{kg})$ and $X$ is phytase activity ( $\mathrm{U} / \mathrm{kg}$ diet). Solution of the equation for $1 \mathrm{~g} P$ gave an equivalency 
Table 6. Second-order translog equations of performance, toe ash, apparent retention of dry matter, calcium and phosphorus and phosphorus excretion of broilers fed on maize-soyabeanmeal diets

\begin{tabular}{|c|c|c|c|c|c|c|c|c|}
\hline \multirow[b]{2}{*}{ Item } & \multicolumn{6}{|c|}{ Coefficients of second-order translog equations ${ }^{*}$} & \multirow{2}{*}{$\begin{array}{c}P \\
\text { value }\end{array}$} & \multirow[b]{2}{*}{$R^{2}$} \\
\hline & $\alpha_{0}$ & $\alpha_{1}$ & $\alpha_{2}$ & $\alpha_{3}$ & $\alpha_{4}$ & $\alpha_{5}$ & & \\
\hline \multicolumn{9}{|l|}{ Performance } \\
\hline Weight gain (g) & $5 \cdot 398$ & 1.034 & 0.0540 & -0.2927 & 0.0032 & -0.0412 & 0.001 & 0.84 \\
\hline Feed intake (g) & 6.033 & 0.884 & 0.0450 & -0.2584 & 0.0024 & -0.0352 & 0.001 & 0.76 \\
\hline Gain/feed $(\mathrm{g} / \mathrm{kg})$ & 6.273 & 0.151 & 0.0090 & -0.0344 & 0.0009 & -0.0060 & 0.028 & 0.15 \\
\hline $\begin{array}{l}\text { Toe ash }(\%) \\
\text { Apparent retention }\end{array}$ & $1 \cdot 280$ & $1 \cdot 228$ & 0.0295 & -0.3761 & 0.0055 & -0.0178 & 0.001 & $0 \cdot 77$ \\
\hline Dry matter & $4 \cdot 263$ & 0.031 & 0.0035 & 0.0054 & 0.0008 & -0.0014 & 0.001 & 0.29 \\
\hline Calcium & 3.648 & $0 \cdot 109$ & 0.0158 & 0.0341 & 0.0050 & -0.0096 & 0.001 & 0.46 \\
\hline Phosphorus & 4.018 & -0.244 & 0.0090 & 0.0821 & 0.0049 & 0.0023 & 0.001 & 0.62 \\
\hline \multicolumn{9}{|c|}{ Apparent retention (g/bird) } \\
\hline Dry matter & 3.516 & 1.774 & 0.0594 & -0.6493 & 0.0042 & -0.0445 & 0.001 & 0.78 \\
\hline Calcium & $-2 \cdot 420$ & $3 \cdot 260$ & -1.096 & -1.096 & 0.0089 & -0.0478 & 0.001 & 0.85 \\
\hline Phosphorus & -1.909 & $1 \cdot 112$ & 0.0664 & -0.1323 & 0.0082 & -0.0404 & 0.001 & 0.79 \\
\hline $\begin{array}{l}\text { Excretion of } P \\
(\mathrm{~g} / \mathrm{kg} \text { DM intake })\end{array}$ & 1.058 & -0.2100 & -0.0160 & 0.4088 & -0.0087 & 0.0012 & 0.001 & 0.88 \\
\hline
\end{tabular}

* Model: $\ln Y=\alpha_{0}+\alpha_{1} \ln X_{1}+\alpha_{2} \ln X_{2}+\alpha_{9}\left(\ln X_{1}\right)^{2}+\alpha_{4}\left(\ln X_{2}\right)^{2}+\alpha_{5} \ln X_{1} \ln X_{2}$; where $Y$ is response measurement, $X_{1}$ is non-phytate $P(\%)$ and $X_{2}$ is phytase added (U/ $/ \mathrm{kg}$ diet).

value of $939 \mathrm{U}$ phytase $/ \mathrm{kg}$. The proportions of $\mathrm{P}$ released from phytate $\mathrm{P}$ were $15,27,36$ and $44 \%$ respectively for $250,500,750$ and $1000 \mathrm{U}$ phytase $/ \mathrm{kg}$ diet. The $\mathrm{P}$ released $(\mathrm{g})$ per $100 \mathrm{U}$ phytase was decreased as the total amount of phytase increased.

During the $21 \mathrm{~d}$ experiment, 14, 0 , and 4 of the broilers died from diets containing $2 \cdot 0$, 2.7 and $3.4 \mathrm{~g} \mathrm{nP} / \mathrm{kg}$. Seven of the fourteen birds that died were from the $2.0 \mathrm{~g} \mathrm{nP} / \mathrm{kg}$ diet without added phytase; the number of deaths declined to normal levels with phytase addition of $200 \mathrm{U} / \mathrm{kg}$ diet or more. In the broilers given 2.7 and $3.4 \mathrm{~g} \mathrm{nP} / \mathrm{kg}$ diet, mortality was normal and not influenced by phytase addition. There were no deaths of broilers given $4.5 \mathrm{~g} \mathrm{nP} / \mathrm{kg}$.

\section{DISCUSSION}

The addition of Natuphos ${ }^{\circledR}$ phytase to the maize-soyabean-meal diets improved all the measurements, especially at the lower $\mathrm{nP}$ levels when fed to broilers during a $21 \mathrm{~d}$ test. These results indicate that microbial phytase is very effective in improving $P$ availability. The maximum growth responses of broilers to phytase level were reduced with increasing levels of dietary $\mathrm{nP}$. The maximum growth responses appeared to occur at 1000, 800 and $600 \mathrm{U}$ phytase $/ \mathrm{kg}$ diet respectively for $2 \cdot 0,2 \cdot 7$ and $3 \cdot 4 \mathrm{~g} \mathrm{nP} / \mathrm{kg}$.

The improved growth responses to the addition of phytase were primarily mediated by the increased feed intake. The improvements of phytase on gain/feed were observed only at $2.0 \mathrm{~g} \mathrm{nP} / \mathrm{kg}$. These results are in agreement with previous findings (Schoner et al. 1991; Vogt, 1992; Denbow et al. 1995). However, the responses for percentage toe ash and the retention (\% of intake and $\mathrm{g} /$ bird) of $\mathrm{P}$ and $\mathrm{Ca}$ of these 1-21-d-old broilers to the supplemental phytase levels did not reach a plateau. It appears that the supplemental phytase may have potential benefits for later growth of broilers which is supported by the findings of Schoner et al. (1993) who fed broilers to $40 \mathrm{~d}$. They reported the $P$ equivalency values of phytase at $14 \mathrm{~d}$ as $1 \mathrm{~g} \mathrm{P}$ as $\mathrm{MCP}=570 \mathrm{U}$ phytase for $\mathrm{BW}$ gain and $1 \mathrm{~g} \mathrm{P}=$ 

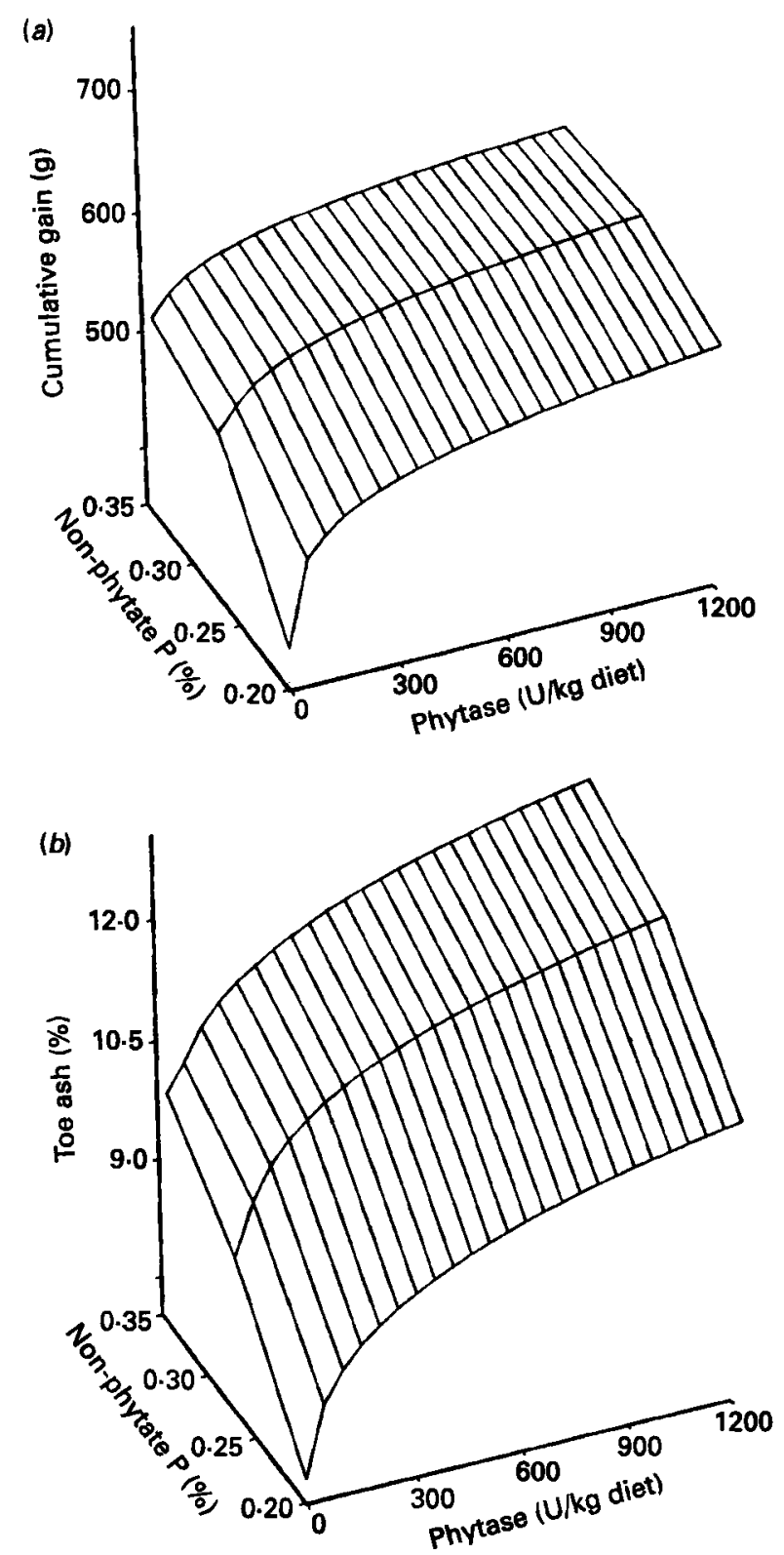

Fig. 1. Body-weight gain (a) and toe ash percentage (b) of broilers fed on maize-soyabean-meal-based diets containing varying amounts of non-phytate phosphorus and supplemental phytase from 1 to $21 \mathrm{~d}$ of age. See Table 6 for coefficients of second-order translog equations.

$1050 \mathrm{U}$ phytase for $\mathrm{P}$ retention. At $40 \mathrm{~d}, 850 \mathrm{U}$ phytase was equal to $1 \mathrm{~g} \mathrm{P}$ for both measurements.

$\mathrm{P}$ excretion ( $\mathrm{g} / \mathrm{kg} \mathrm{DM}$ intake) decreased linearly with increasing amounts of phytase in the present experiment (Table 5). The magnitude of the reduction in $P$ excretion was greater at 2.0 and $2.7 \mathrm{~g} \mathrm{nP} / \mathrm{kg}$ than at $3.4 \mathrm{~g} \mathrm{nP} / \mathrm{kg}$. This result indicates that microbial phytase provides a means of reducing $\mathbf{P}$ pollution in poultry manure. In comparison with the 


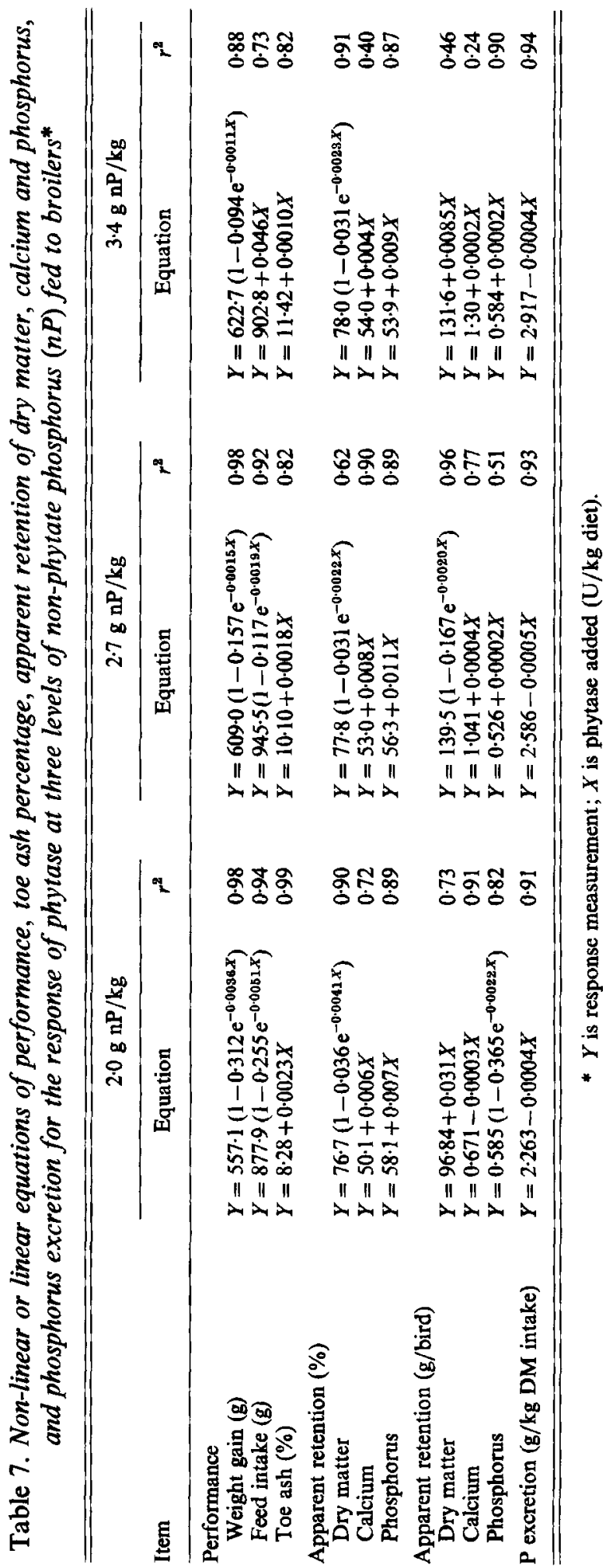


PHYTASE FOR BROILERS

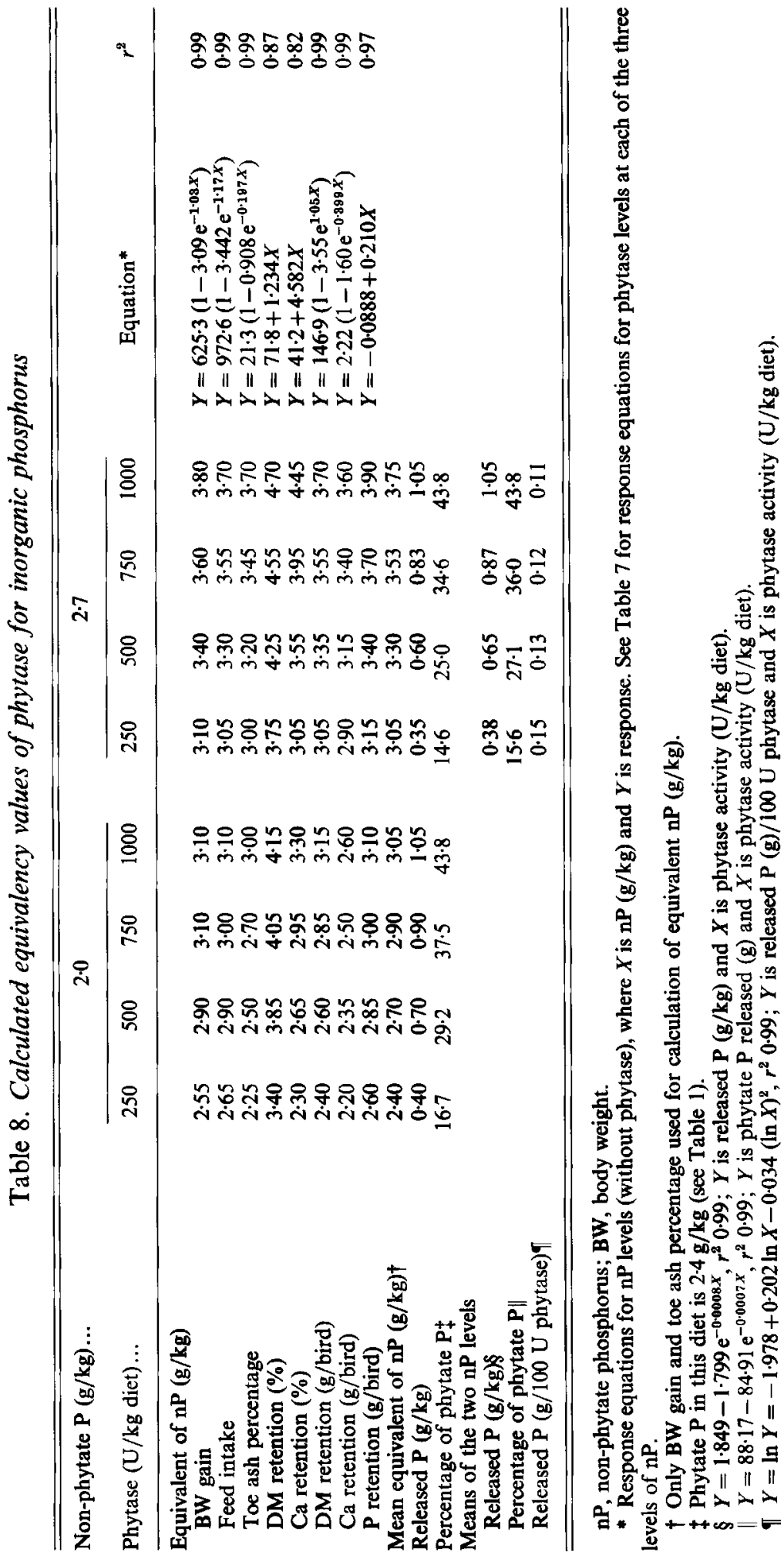


positive control level of $\mathrm{nP}(4.5 \mathrm{~g} / \mathrm{kg}), \mathrm{P}$ excretion was reduced by $25-54 \%$ with addition of 200-1200 U phytase/kg diet. In terms of the model of Schoner et al. (1990) in which one manure unit corresponded to 350 broilers with a $\mathrm{P}$ discharge of $55 \mathrm{~kg} \mathrm{P}_{2} \mathrm{O}_{5}$ /year, adding phytase could increase the number of broilers per manure unit from 350 to 435 or 525 for the same amount of $P$ excretion. This result confirms the finding of Yi et al. (1996).

The results presented here indicate that supplemental phytase improved $\mathrm{Ca}$ availability with the increase of apparent retention ( $\%$ of intake) and total amount of $\mathrm{Ca}$ retained (g/bird). These findings are supported by other observations (Schoner et al. 1991, 1993; Yi et al. 1996). In a broiler study designed to measure the effect of phytase on Ca availability, Schoner et al. (1994) reported that $500 \mathrm{U}$ microbial phytase was equivalent to $0.35 \mathrm{~g} \mathrm{Ca}$ as measured by $\mathrm{BW}$ gain and $0.56 \mathrm{~g} \mathrm{Ca}$ as measured by phalanx ash. Phytic acid can form insoluble salts with $\mathrm{Ca}^{2+}$ (Oberleas, 1973; Morris, 1986), potentially rendering $\mathrm{Ca}$ unavailable for intestinal absorption. Phytase has the ability to release $\mathrm{Ca}^{2+}$ from the insoluble salts and makes $\mathrm{Ca}$ available for absorption in broilers.

The results of the present experiment demonstrate that the measurements of $\mathrm{BW}$ gain, feed intake, toe ash percentage, apparent retention (\% of intake) of $\mathrm{Ca}$ and $\mathrm{P}$, total amount retention ( $\mathrm{g} /$ bird) of $\mathrm{DM}, \mathrm{Ca}$ and $\mathrm{P}$, and $\mathrm{P}$ excretion are sensitive indicators for measuring the efficacy of phytase. BW gain and toe ash percentage were found to be sensitive measurements to evaluate $P$ availability in diets of poultry (Simons et al. 1990; Schoner et al. 1993; Yi et al. 1996). Several tibia, metatarsal and toe measurements, as well as BW gain, were examined in broilers given deficient to adequate levels of $P$ from seven $P$ sources and a dicalcium phosphate dehydrate standard for 3 weeks (Ravindran et al. 1995b). It was found that BW gain and toe ash percentage were equally or more sensitive for assessment of $\mathbf{P}$ availability than tibia ash, and that other measurements, including tibia specific gravity, tibia shear force, toe shear force and metatarsal shear force, were of limited value. Birds are sensitive to dietary $\mathbf{P}$ because of their characteristic low $\mathbf{P}$ storage and fast growth. Retention (\% of intake and $\mathrm{g} / \mathrm{bird}$ ) directly reflected the absorption and utilization of dietary $\mathbf{P}$ in the body of broilers. Thus, these measurements are useful in predicting the responses to supplemental $\mathbf{P}$ and phytase. Measurement of the total amount of $\mathbf{P}$ retained ( $\mathrm{g} / \mathrm{bird}$ ) appears to be even better than that of apparent retention ( $\%$ of intake) of $\mathrm{P}$. This was also observed in the study of Schoner et al. (1993). However, because of their economic importance, ease of determination and sensitivity, BW gain and toe ash percentage may be the measurements of choice in many situations.

The results of the present experiment indicate that about $939 \mathrm{U}$ phytase was required to replace $1 \mathrm{~g}$ inorganic $\mathbf{P}$ as defluorinated phosphate based on equally weighted $\mathrm{BW}$ gain and toe ash percentage for equivalent $P$ values averaged across 2.0 and $2.7 \mathrm{~g} \mathrm{nP} / \mathrm{kg}$ (Table 8). This value was obtained using the non-linear equation $Y(\mathrm{~g} \mathrm{P})=1.849$ $-1.799 \mathrm{e}^{-0.0008 X(\mathrm{U} \text { phytase) }}$. The amount of $P$ released per $100 \mathrm{U}$ phytase decreased as the total amount of phytase was increased. Yi et al. (1996) reported P equivalency values of $1598 \mathrm{U}$ phytase in Expt 1 and $922 \mathrm{U}$ in Expt 2 for broilers fed on a similar soyabean-mealbased diet at $2.7 \mathrm{~g} \mathrm{nP} / \mathrm{kg}(4.5 \mathrm{~g} \mathrm{tP} / \mathrm{kg})$, but they reported a lower $\mathrm{P}$ equivalency value (766 U phytase) for broilers fed on a maize-soyabean-meal diet at $2.7 \mathrm{~g} \mathrm{nP} / \mathrm{kg}$. Denbow et al. (1995) reported that released $P$ values were higher at the higher phytase levels for $2.0 \mathrm{~g} \mathrm{nP} / \mathrm{kg}(3.8 \mathrm{~g} \mathrm{tP} / \mathrm{kg})$ compared with $2.7 \mathrm{~g} \mathrm{nP} / \mathrm{kg}(4.5 \mathrm{~g} \mathrm{tP} / \mathrm{kg})$. The $\mathrm{P}$ equivalency values of phytase for $1 \mathrm{~g} \mathrm{P}$ were $609 \mathrm{U}$ and $1133 \mathrm{U}$ respectively for 2.0 and $2.7 \mathrm{~g} \mathrm{nP} / \mathrm{kg}$. The $P$ equivalency value for the average of the two $P$ levels was $821 \mathrm{U}$ phytase.

Schoner et al. (1991) reported that $700 \mathrm{U}$ phytase was equivalent to $1 \mathrm{~g} \mathrm{P}$ as MCP when $P$ retention data from broilers fed on a maize-soyabean-meal diet for $14 \mathrm{~d}$ were used in the calculation; a value of $762 \mathrm{U}$ phytase was obtained when the calculation was based on crude ash in the total body. The diet used by Schoner et al. (1991) contained $6 \mathrm{~g} \mathrm{Ca} / \mathrm{kg}$ and 
$4.5 \mathrm{~g} \mathrm{tP} / \mathrm{kg}$ that included $1 \mathrm{~g} / \mathrm{kg}$ as MCP. Schoner et al. (1993) used a maize-soyabeanmeal basal diet $(6 \mathrm{~g} \mathrm{Ca} / \mathrm{kg}$ and $3.5 \mathrm{~g} \mathrm{tP} / \mathrm{kg})$ with no added inorganic $P$. They reported the $\mathrm{P}$ equivalency values of phytase at $14 \mathrm{~d}$ as $1 \mathrm{~g} \mathrm{P}$ as $\mathrm{MCP}=570 \mathrm{U}$ phytase for $\mathrm{BW}$ gain and $1 \mathrm{~g} \mathrm{P}=1050 \mathrm{U}$ phytase for $\mathrm{P}$ retention. At $40 \mathrm{~d}, 850 \mathrm{U}$ phytase was equal to $1 \mathrm{~g} P$ for both measurements. Simons \& Versteegh (1993) suggested for broilers during the first $14 \mathrm{~d}$ that $250 \mathrm{U}$ phytase was equivalent to $0.5 \mathrm{~g} \mathrm{P}$ as MCP. Our interpretation of their data suggests that the response per $250 \mathrm{U}$ phytase decreased as the amount of phytase was increased from 500 to $750 \mathrm{U} / \mathrm{kg}$ diet; inorganic $P$ was reduced in the diet as the amount of phytase increased. The difference in $P$ equivalency values may be due to diet type, response indicators, and inorganic $P$ level and source used.

In the calculation of $P$ equivalency values in the present experiment, all the data for birds given $3.4 \mathrm{~g} \mathrm{nP} / \mathrm{kg}$ diet were omitted because of the inconsistency of response measurements (Table 7). The $r^{2}$ values for the equations of $\mathrm{Ca}$ retention ( $\%$ of intake and $\mathrm{g} / \mathrm{bird}$ ) were low. Since $3.4 \mathrm{~g} \mathrm{nP} / \mathrm{kg}$ was closer to the optimum level of $\mathrm{P}$ (NRC (1994) recommended $4.5 \mathrm{~g} \mathrm{nP} / \mathrm{kg}$ ) than were 2.0 and $2.7 \mathrm{~g} / \mathrm{kg}$, phytase-released $\mathrm{P}$ at $3.4 \mathrm{~g} \mathrm{nP} / \mathrm{kg}$ was less than that at 2.0 and $2.7 \mathrm{~g} \mathrm{nP} / \mathrm{kg}$. This indicates that the responses of phytase in maize and soyabean meal were influenced by the dietary $\mathrm{nP}$ level. This is supported by the findings from the in vitro study by Irving \& Cosgrove (1974). They found that inorganic orthophosphate was an inhibitor of Aspergillus ficuum phytase.

The wide Ca: $\mathrm{tP}$ ratio (2:1) used in the present experiment probably reduced the overall response to phytase and inorganic P. Schoner et al. (1993) reported that feeding high levels of $\mathrm{Ca}$ with a constant low level of $\mathrm{tP}(3.5 \mathrm{~g} / \mathrm{kg})$ reduced the increase in BW gain, feed intake, and $\mathbf{P}$ and $\mathrm{Ca}$ retention resulting from added phytase. Their $\mathrm{Ca}: \mathrm{tP}$ ratios were $1 \cdot 71: 1,2 \cdot 14: 1$ and $2 \cdot 57: 1$ from the lowest to the highest level of $\mathrm{Ca}$. Similar negative effects of widening the $\mathrm{Ca}: \mathrm{tP}$ ratio on these response measurements were observed for the lower levels of inorganic P, but not for the higher levels. In our laboratory, Qian et al. (1996) found negative effects on response measurements (BW gain, feed intake, gain/feed, toe ash percentage, $P$ and $\mathrm{Ca}$ retention) of widening the $\mathrm{Ca}: \mathrm{tP}$ ratio $(1 \cdot 1: 1$ to $2: 1)$ at each phytase level $(0,300,600$ or $900 \mathrm{U} / \mathrm{kg}$ diet $)$ and each $P$ level $(2.7$ and $3.6 \mathrm{~g} \mathrm{nP} / \mathrm{kg})$. The magnitude of the effect of widening the $\mathrm{Ca}$ : $\mathbf{t P}$ ratio was much larger at the lower $\mathrm{P}$ level. For example, widening the $\mathrm{Ca}$ : $\mathrm{tP}$ ratio from $1 \cdot 4: 1$ to $2: 1$ decreased phytase efficiency by $7 \cdot 4 \%$ for the $2.7 \mathrm{~g} \mathrm{nP} / \mathrm{kg}$ diets and $4.9 \%$ for the $3.4 \mathrm{~g} \mathrm{nP} / \mathrm{kg}$ diets.

The results of the present experiment clearly demonstrate that the response of microbial phytase is influenced by the dietary level of $\mathrm{nP}$ and that the release of $\mathrm{P}$ per unit of phytase decreases as the amount of phytase increases per unit of diet. The optimal amount of microbial phytase to add to a broiler diet will depend on the response of phytase ( $P$ equivalent value), the cost of phytase and $P$, and the disposal cost of $P$ excreted.

Appreciation is expressed to the United Soybean Board and the John Lee Pratt Animal Nutrition Program for financial support, to BASF Corp., 3000 Continental Drive North, Mount Olive, NJ 07828-1234, USA, for supplying the phytase, to Barbara Self, Lisa Flory and Donald Conner Jr for their able technical assistance, to Cindy Hixon for typing, to Hao Qian for help with data collection, and to Anya McGuirk for advice and help with derivation and plotting of translog functions. This material is based on work supported in part by the Cooperative State Research Service, USDA, under project no. 6129880.

\section{REFERENCES}

Association of Official Analytical Chemists (1990). Official Methods of Analysis, 15th ed. Arlington, VA: AOAC. Consortium (1988). Guide for the Care and Use of Agricultural Animals in Agricultural Research and Teaching. 
Champaign, IL: Consortium For Developing a Guide For the Care and Use of Agricultural Animals in Agricultural Research and Teaching.

Denbow, D. M., Ravindran, V., Kornegay, E. T., Yi, Z. \& Hulet, R. M. (1995). Improving phosphorus availability in soybean meal for broilers by supplemental phytase. Poultry Science 74, 1831-1842.

Driscoll, P. J. (1994). When flexible forms are asked to flex too much. Journal of Agricultural and Resource Economics 19, 183-196.

Engelen, A. J., van der Heeft, F. C., Randsdorp, P. H. G. \& Smit, E. L. C. (1994). Simple and rapid determination of phytase activity. Journal of the Association of Official Analytical Chemists International 77, $760-764$.

Irving, G. C. J. \& Cosgrove, D. J. (1974). Inositol phosphate phosphatases of microbiological origin. Some properties of the partially purified phosphatases of Aspergillus ficuum NRRL 3135. Australian Journal of Biological Sciences 27, 361-368.

Morris, E. R. (1986). Phytate and dietary mineral bioavailability. In Phytic Acid: Chemistry and Applications, pp. 57-76. [E. Graf, editor]. Minneapolis: Pilatus Press.

National Research Council (1994). Nutrient Requirements of Poultry, 9th ed. Washington, DC: National Academy of Sciences.

Nelson, T. S., Schieh, T. R., Wodzinski, R. J. \& Ware, J. H. (1968). The availability of phytate phosphorus in soybean meal before and after treatment with a mold phytase. Poultry Science 47, 1842-1848.

Oberleas, D. (1973). Phytates. In Toxicants Occurring Naturally in Food, pp. 363-371. Washington, DC: National Academy of Sciences.

Potter, L. M. (1988). Bioavailability of $P$ from various phosphates based on body weight and toe ash measurements. Poultry Science 67, 96-102.

Potter, L. M., Potchanakorn, M., Ravindran, V. \& Kornegay, E. T. (1995). Bioavailability of phosphorus in various phosphate sources using body weight and toe ash as response criteria. Poultry Science 74, 813-820.

Qian, H., Kornegay, E. T. \& Denbow, D. M. (1996). Phosphorus equivalence of microbial phytase in turkey diets as influenced by $\mathrm{Ca}: \mathrm{P}$ ratios and $\mathrm{P}$ levels. Poultry Science 75, 69-81.

Ravindran, V., Kornegay, E. T., Denbow, D. M., Yi, Z. \& Hulet, R. M. (1995a). Response of turkey poults to tiered levels of Natuphos phytase added to soybean meal-based semi-purified diets containing three levels of nonphytate phosphorus. Poultry Science 74, 1843-1854.

Ravindran, V., Kornegay, E. T., Potter, L. M., Ogunbamer, B. W., Welten, M. K., Wilson, J. H. \& Potchanakorn, M. (1995b). An evaluation of various response criteria in assessing biological availability of phosphorus for broilers. Poultry Science 74, 1820-1830.

Schoner, F. J., Hoppe, P. P. \& Schwarz, G. (1991). Comparative effects of microbial phytase and inorganic phosphorus on performance and on retention of phosphorus, calcium and crude ash in broilers. Journal of Animal Physiology and Animal Nutrition 66, 248-255.

Schoner, F. J., Hoppe, P. P., Schwarz, G. \& Wiesche, H. (1993). Effects of microbial phytase and inorganic phosphate in broiler chickens: performance and mineral retention at various calcium levels. Journal of Animal Physiology and Animal Nutrition 69, 235-244.

Schoner, F. J., Schwarz, G. \& Hoppe, P. P. (1990). Influence of the P compound on the P and Ca retention and the $\mathrm{P}$ discharge in broilers. 102nd VDLUFA Congress, Berlin 32, 437-442.

Schoner, F. J., Schwarz, G., Hoppe, P. P. \& Wiesche, H. (1994). Effects of microbial phytase on Ca utilization in broilers. Third Conference on Poultry and Swine Nutrition, Halle, Germany, 29 November-1 December, pp. 147-150.

Simons, P. C. M. \& Versteegh, H. A. J. (1993). Role of phytase in poultry nutrition. In Proceedings 1st Symposium of Enzymes in Animal Nutrition, Kartause, Ittingen, Switzerland, 13-16 October, pp. 181-186 [C. Wenk and M. Boessinger, editors]. Zurich: Schriftenreihe aus dem Institut fur Nutztierwissenschaften Gruppe Ernahrung ETH.

Simons, P. C. M., Versteegh, H. A. J., Jongbloed, A. W., Kemme, P. A., Slump, P., Bos, K. D., Wolters, M. G. E., Beudeker, R. F. \& Verschoor, G. J. (1990). Improvement of phosphorus availability by microbial phytase in broilers and pigs. British Journal of Nutrition 64, 525-540.

Statistical Analysis Systems (1990). SAS/STAT User's Guide: Statistics, release 6.04. Cary, NC: SAS Institute Inc.

Vogt, H. (1992). Effect of supplemental phytase to broiler rations different in phosphorus content. European Poultry Science 56, $93-98$.

Yi, Z., Kornegay, E. T., Ravindran, V. \& Denbow, D. M. (1996). Improving phytate phosphorus availability in corn and soybean meal for broilers using microbial phytase and calculation of $P$ equivalency values for phytase. Poultry Science 75, 240-249. 